\title{
FAKTOR PERSEPSI INDIVIDU DALAM PENGEMBANGAN PERIKANAN LINTAS BATAS
}

\author{
(Perception of the Individual Factor in Transboundary Fisheries Development)
}

\author{
Romelus Far-Far ${ }^{1}$, John Haluan ${ }^{2}$, Mulyono S Baskoro² ${ }^{2}$, Victor Nikijuluw ${ }^{3}$
}

\begin{abstract}
Manage of fisheries resource in border area would dependent about as long as behaviour and perception of community to response their problems. This paper would analyses about factor of individual perception to development fisheries transboundary such as fitting of historical, fishing gears, production, and marketing location; knowledge source about owner region and partial model of fishermen perception in Lirang, Wetar and Kisar Islands. Partial model of individual perception TCIF (Transboundary Commuters for Illegal Fishing) are e $-1,372+0,846$ SPKW $+1,029$ PAN-TL or P (TCIF_individual perception $)=f(S P K W, P A N-T L)$.
\end{abstract}

Keywords : individual perception, fishermen, transboundary

\begin{abstract}
ABSTRAK
Mengelola sumber daya perikanan di wilayah perbatasan akan tergantung pada perilaku dan persepsi masyarakat untuk memberi reaksi terhadap masalah mereka. Makalah ini akan menganalisis tentang faktor persepsi individu untuk pengembangan perikanan lintas batas seperti pemasangan sejarah, alat penangkapan ikan, produksi, dan lokasi pemasaran, sumber pengetahuan tentang wilayah pemilik dan model parsial persepsi nelayan di Lirang, Wetar dan Kepulauan Kisar. Model parsial persepsi individu TCIF (Transboundary Commuters for Illegal Fishing) adalah $\mathrm{e}^{-1,372+0,846}$ $\mathrm{SPKW}+1,029$ PAN-TL atau P $($ TCIF_ individual perception $)=\mathrm{f}(\mathrm{SPKW}, \mathrm{PAN}-\mathrm{TL})$.
\end{abstract}

Kata kunci : persepsi individu, nelayan, lintas batas

\section{PENDAHULUAN}

\subsection{Latar belakang}

Tantangan yang dihadapi untuk dapat mengelola sumber daya ikan secara berkelanjutan di perairan Indonesia menjadi sangat berat karena maraknya praktekpraktek penangkapan ikan yang oleh dunia internasional disebut sebagai kegiatan perikanan yang illegal, unreported and unreguated (IUU-fishing). IUU Fishing dapat terjadi di semua kegiatan perikanan tangkap tanpa tergantung pada lokasi, target spesies, alat tangkap yang digunakan serta intensitas exploitasi. Dapat muncul di semua tipe perikanan baik skala kecil dan industri, perikanan di zona juridiksi nasional maupun internasional.

Dalam konteks geografis, banyak permasalahan yang dihadapi oleh masyarakat di kawasan perbatasan sebagai akibat lemahnya aksesibilitas.

Permasalahan yang dihadapi wilayah perbatasan Indonesia berbeda sifat dan kondisinya dengan kawasan lain.
Permasalahan-permasalahan yang terjadi di wilayah perbatasan dipengaruhi oleh faktor yang berbeda seperti geografis, ketersediaan sumber daya manusia dan alam, kondisi sosial, ekonomi, politik, dan budaya serta tingkat kesejahteraan masyarakat negara tetangga.

Sebagian besar wilayah perbatasan di Indonesia masih merupakan kawasan tertinggal dengan sarana dan prasarana sosial dan ekonomi yang masih sangat terbatas. Pandangan di masa lalu bahwa wilayah perbatasan merupakan kawasan yang perlu diawasi secara ketat karena menjadi tempat persembunyian para pemberontak telah menjadikan paradigma pembangunan perbatasan lebih mengutamakan pada pendekatan keamanan (security approach) daripada pendekatan kesejahteraan (prosperity approach). Akibatnya, wilayah perbatasan di beberapa daerah menjadi daerah yang tidak tersentuh oleh dinamika pembangunan dan masyarakat di wilayah perbatasan pada

\footnotetext{
${ }^{1}$ Kepala Dinas Koperasi UMKM Maluku

${ }^{2}$ Staf Pengajar Departemen Pemanfaatan Sumberdaya Perikanan, FPIK IPB

${ }^{3}$ Staf Kementerian Kelautan dan Perikanan
} 
umumnya miskin serta diprediksi banyak yang berorientasi pada negara tetangga. Di lain pihak, salah satu negara tetangga, yaitu Malaysia, telah membangun pusat-pusat pertumbuhan dan koridor perbatasannya melalui berbagai kegiatan ekonomi dan perdagangan yang telah memberikan keuntungan bagi pemerintah maupun masyarakatnya.

Pengelolaan sumberdaya perikanan di wilayah perbatasan akan dipengaruhi oleh sejauhmana sikap dan persepsi masyarakat dalam merespon permasalahan yang dihadapinya. Masalah penting dalam pengelolaan perikanan di wilayah perbatasan adalah soal status sumberdaya ikan. Sumberdaya ikan di seluruh dunia saat ini menghadapi tekanan eksploitasi yang sangat tinggi. Hasil evaluasi badan dunia FAO (Food and Agriculture Organization) tahun 1998 menunjukkan bahwa empat dari 16 perairan telah mencapai puncak pemanfaatan sumber daya ikannya, delapan wilayahnya telah dimanfaatkan sekitar lebih dari $70 \%$, sementara empat lainnya telah dimanfaatkan antara 10\% - 50\%. Wilayah perairan Indonesia yang termasuk dalam wilayah 57 yaitu perairan kawasan Timur dan Utara serta wilayah 71 yaitu perairan kawasan Barat dan Selatan, termasuk yang dinyatakan sebagai kawasan yang pemanfaatan sumber dayanya sudah mencapai puncak (Nikijuluw, 2005 dan Mouse et al., 2005).

\subsection{Tujuan}

Tujuan penelitian adalah mengkaji dan menganalisis faktor persepsi individu dalam pengembangan perikanan lintas batas :

(1) Persepsi individu mengenai pengetahuan tentang kepemilikan wilayah, aktivitas nelayan, dan kepemilikan fishing ground

(2) Model parsial persepsi individu nelayan-nelayan Lirang, Wetar dan Kisar (LWK).

\section{METODOLOGI}

Persepsi individu yang dimaksudkan sebagai salah satu variabel penelitian, mencakup dua aspek kajian, yaitu :

(1) Kepemilikan dengan faktor-faktor yang dikaji, antara lain : user, owner, precipitor, dan claimant;

(2) Hak yang diklaim dengan faktor-faktor yang dikaji, antara lain: akses, meman- faatkan, mengatur atau menata, eksklusif dan mengalihkan ke pihak lain.

\section{Metode Analisis}

Berdasarkan kerangka pemikiran yang telah dikemukakan, maka dalam menganalisis faktor Persepsi Individu telah ditetapkan 3 (tiga) variabel di antaranya:

1. Sumber Pengetahuan tentang Kepemilikan Wilayah (PI-1)

Analisis dengan model regresi logistik biasanya hanya terdiri atas dua nilai, yang mewakili kemunculan atau tidak adanya suatu kejadian yang biasanya diberi angka 0 atau 1 . Dengan demikian maka diasumsikan bahwa masyarakat LWK melakukan aktivitas penangkapan ikan yang melintasi batas wilayah NKRI dipengaruhi oleh sumber pengetahuan nelayan tentang kepemilikan wilayah baik dari pemerintah maupun dari sumber lainnya seperti sejarah desa, tokoh masyarakat, tokoh adat, atau kriteria dari orang tua secara turuntemurun. Sehingga variabel dependen untuk PI-1 di tulis sebagai berikut :

$\begin{array}{ll}\text { Sumber lain } & =1 \\ \text { Sumber dari Pemerintah } & =0\end{array}$

2. Pengetahuan tentang Aktivitas Nelayan RDTL (PI-2)

Pengetahuan nelayan LWK tentang aktivitas nelayan RDTL yang menangkap di wilayah LWK merupakan komponen yang dianalisis. Hipotesis yang dibangun adalah bahwa hubungan persaudaraan/kekeluargaan antara masyarakat RDTL dan LWK yang selama ini terbangun mengakibatkan aktivitas nelayan RDTL yang menangkap di wilayah LWK dianggap sebagai hal biasa dan bukan suatu bentuk pelanggaran lintas batas. Sehingga variabel dependen (respon) untuk PI-2 di tulis sebagai berikut :

Pernah menjumpai nelayan RDTL menang kap di LWK $=1$

Lainnya $=0$

3. Pengetahuan tentang Kepemilikan Fishing Ground Nelayan RDTL (PI-3)

Sebagai akibat dari hubungan kekeluargaan diantara masyarakat LWK dan RDTL dapat saja merubah presepsi masyarakat kedua wilayah untuk memiliki hak yang sama dalam pemanfaatan sumberdaya ikan di dua kawasan. Untuk itulah maka hipotesis yang dibangun adalah bahwa jika masyarakat nelayan LWK masih menganggap masyarakat nelayan RDTL memiliki hak menangkap di wilayah LWK, 
maka akan memberikan peluang yang besar untuk terjadinga violence atau pelanggaran lintas batas dan sebaliknya. Sehingga variabel dependen (respon) untuk PI-3 di tulis sebagai berikut:

$\begin{array}{ll}\text { Nelayan RDTL memiliki hak } & =1 \\ \text { Lainnya } & =0\end{array}$

4. Model Analisis TCIF Persepsi Individu

Berdasarkan model umum yang digunakan pada regresi logistic serta memperhatikan berbagai variabel yang dibangun dalam Faktor Persepsi Individu, maka model matematik yang ditetapkan adalah sebagai berikut (Nikijuluw, 2008):

$\operatorname{Ln} \frac{p}{1-p}=\beta_{0}+\beta_{1} \mathrm{PI}-1+\beta_{2} \mathrm{PI}-2+\beta_{3} \mathrm{PI}-3 \ldots$

Jika :

(PI-1) dinotasikan dengan $=$ SPKW

(PI-2) dinotasikan dengan $=$ PAN-TL

(PI-3) dinotasikan dengan $=$ FGN-TL

Maka model menjadi:

$\operatorname{Ln} \frac{p}{1-p}=\beta_{0}+\beta_{1} \mathrm{SPKW}+\beta_{2} \mathrm{PAN}-\mathrm{TL}+\beta_{3} \mathrm{FGN}-\mathrm{TL}$

atau

$\frac{p}{1-p}=\mathrm{e}^{\beta 0+\beta 1 \mathrm{SPKW}+\beta 2 \mathrm{PAN}-\mathrm{TL}+\beta 3 \mathrm{FGN}-\mathrm{TL}}$

atau dapat ditulis:

Model TCIF-PI $=e^{\beta 0+\beta 1 S P K W}+\beta 2 P A N-T L+\beta 3 F G N-T L$

\section{HASIL DAN PEMBAHASAN}

\subsection{Persepsi Individu}

(1) Faktor - Faktor Yang Menentukan Persepsi

Wilayah ini berbatasan dengan $\mathrm{Re}$ publik Demokratik Timor Leste dan Samudera Hindia di sebelah selatan, Alor (Nusa Tenggara Timur) di sebelah barat, MTB di sebelah Timur, dan Kepulauan Lucipara dalam Laut Banda di sebelah utara. Jarak Wetar dengan Atauro (bekas daerah administratif ke-18 eks Provinsi Timor-Timor) sekitar 25 mil laut atau $40 \mathrm{Km}$ di daratan. Sementara antara Baucau (salah satu distrik di RDTL) dengan Kisar dan Leti sekitar 18 mil laut.

Berdasarkan posisi geokultural, hubungan kekerabatan antara penduduk Timor Leste dan warga MBD sudah lama terpatri melalui kawin-mawin maupun dari pendekatan kesamaan bahasa (bandingkan dengan hasil penelitian Corneles van Vollenhoven yang membagi Indonesia ke dalam "19 Kesatuan Hukum Adat" dan Goris Keraf yang membagi Indonesia juga dalam beberapa rumpun bahasa dan adat istiadat).

Kondisi di atas sangat mempengaruhi presepsi masyarakat nelayan LWK untuk melakukan kegaiatan penangkapan di wilayah RDTL dan sebaliknya masyarakat RDTL melakukan aktivitas penangkapan di wilayah LWK. Disamping kedekatan jarak dan lainnya yang telah disebutkan diatas, faktor-faktor lain yang dianggap sangat mempengaruhi persepsi nelayan kedua wilayah adalah :

a. Kesesuaian Sejarah

Letak geografis yang berdekatan, menyebabkan banyak ditemukannya kesamaan-kesamaan antara penduduk LWK dengan RDTL, yang walaupun secara kedaulatan, keduanya memiliki perbedaan. Persamaan yang pertama yaitu persamaan agama yang dipeluk oleh penduduk kedua daerah. Agama Katolik, Kristen Protestan dan Islam merupakan agama-agama yang dipeluk oleh penduduk kedua wilayah.

Kedua wilayah ini juga memiliki kemiripan dalam hal adat dan budaya. Pakaian adat yang mencirikan budaya masyarakat LWK juga ditemukan pada pakaian adat masyarakat RDTL. Bahan yang digunakan sebagai material pembuatan pakaian adat kedua wilayah juga memiliki kemiripan. Bahan pakaian adatnya terbuat dari kain tenun dilengkapi dengan senikir (semacam selendang). Selain itu, pada pakaian adat tersebut juga dilengkapi dengan senjata semacam keris dan mahkota pada kepalanya. Hal yang sama juga berlaku untuk tari-tarian adat masyarakat LWK yang juga ditemukan pada acara/ pertunjukkan adat masyarakat RDTL. Tari Peuk merupakan tarian yang menggambarkan suasana masyarakat saat berperang yang ditemukan pada kedua daerah. Dalam kaitannya dengan pemeliharaan lingkungan dan SDA, kearifan lokal di adat dan budaya yang juga ada di RDTL yaitu sasi. Letak geografis wilayah yang berdampingan juga memiliki konsekuensi kepada cara berkomunikasi masyarakat kedua daerah. Bahasa Tetun merupakan bahasa yang digunakan pada kedua lokasi.

\section{b. Kesesuaian Alat Tangkap}

Beberapa alat tangkap yang samasama dioperasikan pada kedua wilayah yaitu pancing, bubu, sero, jaring, perahu dan motor tempel. Sementara itu, masyarakat dari kedua wilayah ini juga sering 
berdatangan ke wilayah yang satu dengan yang lain. Tujuan kedatangan mereka antara lain untuk melakukan aktifitas penangkapan. Desa-desa LWK yang sering menangkap di perairan LWK-RDTL antara lain nelayan-nelayan yang berasal dari desa Ilwaki, Arnau, Lirang, Wonreli, Abusur, Kota Lama, Lebelau, Lekloor dan Oirata. Sementara desa-desa RDTL yang sering melakukan aktifitas penangkapan di LWK-RDTL antara lain dari desa Laga Mulia, Atauru, Lautem dan Karo.

\section{c. Kesesuaian Hasil Tangkapan}

Jenis-jenis ikan yang berhasil ditangkap oleh nelayan kedua wilayah antara lain: ikan momar, ikan kawalinya, ikan julung, ikan karang, ikan cakalang, ikan tuna ekor kuning, ikan tenggiri, ikan lamadang, ikan putilai, ikan layar dan ikan hiu.

Daerah yang menjadi tujuan penangkapan dari nelayan-nelayan LWK-RDTL juga ada yang sama. Bahkan nelayan-nelayan LWK ada juga yang bepergian ke perairan RDTL untuk melakukan aktifitas penangkapan, demikian juga sebaliknya. Lokasi penangkapan di LWK yang sering didatangi oleh nelayan-nelayan RDTL antara lain Selat Romang-Wetar, Selat Kisar-Serwaru, Selat Wetar-Kisar. Sebaliknya lokasi penangkapan di RDTL yang sering didatangi oleh nelayan-nelayan dari LWK antara lain Yako, Koum, Kolam dan Laga.

\section{d. Kesesuaian Lokasi Pemasaran}

Hasil tangkapan yang diperoleh oleh para nelayan biasanya dipasarkan dan juga dimanfaatkan menjadi konsumsi harian rumah tangga mereka. Selain hasil tangkapan tersebut dibawa pulang kemudian dijual ke desa masing-masing, namun berdasarkan laporan dari para nelayan LWK, ada juga yang langsung menjual hasil tangkapan mereka di RDTL. Hal yang mendorong terjadinya hal tersebut karena nilai jual ikan di RDTL sangat tinggi dibandingkan ketika hasil tangkapan mereka jual di LWK. Komoditi yang dipasarkan olah nelayan-nelayan kedua wilayah adalah hasil tangkapan ikan.

(2) Sumber Pengetahuan tentang Kepemilikan Wilayah

Pemanfaatan sumberdaya perikanan oleh nelayan di kawasan LWK didasarkan atas pengetahuan mereka tentang kepemilikan dan hak pengusahaan wilayah mereka. Berdasarkan hasil wawancara dengan nelayan di LWK didapatkan bahwa sumber pengetahuan kepemilikan wilayah mereka diperoleh dari proses pembelajaran terhadap aturan-aturan formal NKRI yang mereka dapatkan baik melalui proses membaca, dan atau mengikuti kegiatan pelatihan/sosialisasi oleh pemerintah daerah setempat maupun dari proses-proses diskusi yang mereka bangun secara berkelompok. Sedangkan pengetahuan kepemilikan wilayah secara formal didapatkan dari membaca sejarah desa atau kawasan maupun mendengar penuturan sejarah dari tokoh-tokoh adat maupun dari orang tua mereka yang menceriterakan keberadaan wilayah mereka secara turun-temurun.

Berdasarkan hasil wawancara didapatkan bahwa hampir sebagian besar $(48,96 \%)$ nelayan di kawasan LWK memiliki pengetahuan terhadap kepemilikan wilayah mereka bersumber dari aturan secara nonformal, sedangkan $13,54 \%$ memiliki pengetahuan yang bersumber dari aturan formal sedang sisanya atau $37,5 \%$ nelayan menyatakan tidak mengetahui tentang aturanaturan baik secara formal maupun nonformal. Dengan merujuk pada hasil analisis tersebut maka dapat dikatakan bahwa aktivitas nelayan terutama bagi mereka yang melakukan kegiatan penangkapan ikan hingga melewati batas wilayah NKRI, adalah juga disebabkan oleh ketidaktahuan nelayan LWK tentang aturan-aturan formal yang berlaku di suatu wilayah perbatasan. Disamping itu pelanggaran terhadap batas wilayah Negara ini juga diakibatkan oleh pengetahuan mereka yang banyak didasarkan atas aturan non-formal yang selama ini dilaksanakan, yang mana hubungan tersebut dilakukan atas dasar kekerabatan diantara masyarakat ke dua Negara.

\subsection{Model Parsial Persepsi Individu TCIF}

Pengembangan Model Parsial TCIF sebagai pengaruh dari faktor persepsi individu dilakukan dengan pendekatan Model Regresi Logistik. Langkah awal dalam pengembangan model ini ialah menilai model fit dengan data faktor-faktor ekonomi yang secara teoritis dipandang memberikan pengaruh terhadap TCIF.

Hasil penilaian model fit yang dilihat dari nilai statistik -2LogL tanpa variabel menunjukkan konstanta sebesar 130,405. Setelah dimasukan dua variabel, nilai 2LogL turun menjadi 120,828 (Tabel 1), hal ini menunjukkan adanya penurunan sebesar 9,577. 
Tabel 1. Hasil Penilaian Model Fit

\begin{tabular}{|c|c|c|c|}
\hline No. & Parameter Model Fit & Nilai & Keterangan \\
\hline 1 & -2Log Likelihood awal & 130,405 & \\
\hline 2 & $\begin{array}{l}\text {-2Log Likelihood setelah } \\
\text { dimasukan } 2 \text { variabel }\end{array}$ & 120,828 & Terjadi penurunan 9,577 \\
\hline 3 & Cox and Snell's R ${ }^{2}$ & 0,095 & $\begin{array}{l}\text { Variabilitas variabel dependen yang dapat } \\
\text { dijelaskan variabilitas variabel independen } \\
9,5 \%\end{array}$ \\
\hline 4 & Nagelkerke $\mathrm{R}^{2}$ & 0,128 & $\begin{array}{l}\text { Variabilitas variabel dependen hanya dapat } \\
\text { menjelaskan variabilitas variabel independen } \\
12,8 \%\end{array}$ \\
\hline 5 & $\begin{array}{l}\text { Hosmer and Lemeshow Test } \\
\left(X^{2}\right)\end{array}$ & 0,240 & $\begin{array}{l}\text { Signifikan pada } 0,887>0,005 \text { (Model fit dan } \\
\text { dapat diterima) }\end{array}$ \\
\hline
\end{tabular}

Hasil analisis lebih lanjut dengan PASW memberikan nilai Cox and Snell's $\mathrm{R}^{2}$ sebesar 0,095 dan nilai Nagelkerke $R^{2}$ sebesar 0,128 . Hal ini berarti variabilitas variabel dependen yang dapat dijelaskan oleh variabilitas variabel independen sebesar $12,8 \%$ (sesuai $\mathrm{R}^{2}$ berdasarkan Uji Nagelkerke).

Hasil ini juga menunjukkan nilai Hosmer-Lemeshow sebesar 0,240 berada pada signifikasi 0,887. Hasil ini memberikan implikasi tingkat signifikasi lebih dari 0,05, sehingga model dikatakan fit dan dapat diterima. Dengan demikian, data empiris memiliki kecocokan atau kesesuaian dengan model.

Lebih lanjut dilakukan analisis ketepatan klasifikasi hasil prediksi dibandingkan dengan hasil observasi lapangan seperti pada Tabel 2. Fokus analisis diarahkan pada matriks klasifikasi 2 x 2 (yang diberikan batas biru), dimana matriks ini menghitung nilai estimasi yang benar dan salah.

Hasil prediksi menunjukkan responden yang berpeluang tidak melakukan violence (kode 0) karena pengaruh faktor persepsi individu sebanyak $46+10$ atau sama dengan 56 orang, sedangkan hasil lapangan menunjukkan hanya 46 orang yang berpeluang tidak melakukan violence sebagai pengaruh faktor persepsi individu. Hasil ini memberikan gambaran ketepatan klasifikasi 46/56 atau 82,1\%.

Hasil prediksi untuk responden yang berpeluang melakukan violence (kode 1) karena pengaruh faktor ekonomi sebanyak $22+18$ atau sama dengan 40 orang, sedangkan hasil lapangan menunjukkan hanya 22 orang yang berpeluang melakukan violence sebagai pengaruh persepsi individu. Hasil ini memberikan gambaran ketepatan klasifikasi 22/40 atau 45,0\%.

Tabel 2. Tabel Ketepatan Klasifikasi Prediksi dibandingkan Observasi

\begin{tabular}{|c|c|c|c|c|c|}
\hline & & & & redicte & \\
\hline & & served & & & Percentage \\
\hline & & & 0 & 1 & Correct \\
\hline Step 1 & V & 0 & 32 & 24 & 57,1 \\
\hline & & 1 & 13 & 27 & 67,5 \\
\hline & & Percentage & & & 61.5 \\
\hline Step 2 & V & 0 & 46 & 10 & 82,1 \\
\hline & & 1 & 22 & 18 & 45,0 \\
\hline & & Percentage & & & 66,7 \\
\hline
\end{tabular}

Berdasarkan pada kedua hasil estimasi tersebut, dapat dilakukan estimasi secara menyeluruh untuk model. Secara keseluruhan hasil estimasi tingkat ketepatan klasifikasi hasil prediksi dibandingkan dengan hasil observasi lapangan terhadap responden terkait dengan faktor persepsi individu adalah $66,7 \%$.
Untuk membentuk model yang sesuai dengan hasil lapangan, maka dilakukan estimasi parameter seperti dihasilkan dalam Tabel 3 tentang variabel-variabel dalam persamaan. Hasil ini menunjukkan dua variabel independen yang signifikan adalah PI1 (Sumber Pengetahuan Tentang Kepemilikan Wilayah) dan PI2 (Pengetahuan Tentang Aktivitas Nelayan RDTL). 
Tabel 3. Variabel-Variabel Dalam Persamaan Persepsi Individu TCIF

\begin{tabular}{|c|c|c|c|c|c|c|c|}
\hline & B & S.E. & Wald & $\mathrm{df}$ & Sig. & $\operatorname{Exp}(B)$ \\
\hline \multirow[t]{2}{*}{ Step $1^{a}$} & PI2 & 1,019 &, 432 & 5,552 & 1 &, 018 & 2,769 \\
\hline & Constant &,- 901 &, 329 & 7,501 & 1 &, 006 &, 406 \\
\hline \multirow[t]{3}{*}{ Step $2^{\mathrm{b}}$} & PI1 &, 846 & 440 & 3,694 & 1 & ,055 & 2,331 \\
\hline & PI2 & 1,029 &, 442 & 5,425 & 1 &, 020 & 2,797 \\
\hline & Constant & $-1,372$ & 427 & 10,316 & 1 & ,001 &, 254 \\
\hline \multicolumn{8}{|c|}{ a. Variable(s) entered on step 1: PI2. } \\
\hline \multicolumn{8}{|c|}{ b. Variable(s) entered on step 2: PI1. } \\
\hline
\end{tabular}

Persamaan regresi logistik yang dapat dikemukakan sesuai dengan hasil estimasi parameter dari faktor persepsi individu yang memberikan pengaruh terhadap violence dapat ditulis sebagai berikut (Nikijuluw, 2008):

$$
\operatorname{Ln} \frac{p}{1-p}=-1,372+0,846 \text { PI } 1+1,029 \text { PI } 2
$$

Jika variabel PI1 dinotasikan dengan SPKW dan variabel PI2 dinotasikan dengan PAN-TL, maka persamaan (6.16) dapat ditulis sebagai berikut:

$\operatorname{Ln} \frac{p}{1-p}=-1,372+0,846 \mathrm{SPKW}+1,029 \mathrm{PAN}-\mathrm{TL} \ldots .$. (6) atau

$\frac{p}{1-p}=\mathrm{e}^{-1,372+0,846 \mathrm{SPKW}+1,029 \text { PAN-TL }}$

atau dapat ditulis:

TCIF Persepsi Individu $=e^{-1,372}+0,846$ SPKW $+1,029$ PAN-TL

Variabel PI1 (SPKW) dan PI2(PAN-TL) signifikan pada 0,05. Berdasarkan persamaan logistik tergambar bahwa peluang responden nelayan LWK melakukan violence (TCIF) yang didorong oleh faktor persepsi individu, rata-rata secara positif dipengaruhi oleh SPKW dan PAN-TL. Hasil ini menunjukkan ketika variabel SPKW dianggap konstan, maka peluang responden nelayan LWK melakukan violence (TCIF) di atas rata-rata faktor $(\mathbf{e}$ 1,029) untuk setiap kenaikan satu unit PAN-TL. Demikian juga, jika variabel PAN-TL dianggap konstan, maka peluang responden nelayan LWK melakukan violence (TCIF) di atas rata-rata faktor (e $\mathbf{0 , 8 4 6})$ untuk setiap kenaikan satu unit SPKW.

Sebagai interpretasi dari hasil tersebut, dapat dikemukakan bahwa semakin tinggi nilai SPKW dan PAN-TL maka peluang responden nelayan LWK melakukan violence (TCIF) semakin tinggi. Hal ini membuktikan bahwa faktor persepsi individu SPKW (Sumber Pengetahuan Tentang Kepemilikan Wila-yah) dan PAN-TL (Pengetahuan Tentang Aktivitas Nelayan RDTL) merupakan variabel yang memberikan pengaruh dalam pembentukan Model persepsi individu TCIF. Sehingga Model Parsial TCIF persepsi individu dapat ditulis sebagai berikut:

$\mathrm{P}\left(\mathrm{TCIF} \_\right.$Persepsi Individu $)=\mathrm{f}(\mathrm{SPKW}, \mathrm{PAN}-\mathrm{TL})$

dimana:

P (TCIF_Persepsi Individu) : Peluang masyarakat nelayan LWK untuk melakukan pergerakan lintas batas untuk melakukan perikanan ilegal (Trans-boundary Comuters for Illegal Fishing/-TCIF) karena dorong faktor persepsi individu.

SPKW : Sumber Pengetahuan Tentang Kepemilikan Wilayah.

PAN-TL : Pengetahuan Tentang Aktivitas Nelayan RDTL.

Secara naratif model di dapat dinyatakan sebagai: "Peluang masyarakat nelayan LWK melakukan pergerakan lintas batas untuk melakukan per(f)lanan ilegal merupakan fungsi dari sumber pengetahuan tentang kepemilikan wilayah dan pengetahuan tentang aktivitas nelayan RDTL".

\section{KESIMPULAN DAN SARAN}

(1) Faktor persepsi individu yang menentukan dalam pengembangan perikanan lintas batas meliputi: kesesuaian sejarah, kesesuaian alat tangkap, kesesuaian hasil tangkapan, dan kesesuaian lokasi pemasaran, serta sumber pengetahuan tentang kepemilikan wilayah.

(2) Dalam mengembangkan perikanan di kawasan Pulau Lirang, Wetar dan Kisar, dapat menggunakan Model TCIF (Transboundary Commuters for Ilegal Fishing) yang dibangun dengan Model Parsial Persepsi Individu TCIF yaitu;

TCIF Persepsi Individu $=\mathrm{e}^{-1,372+0,846 \mathrm{SPKW}+1,029 \text { PAN-TL }}$ atau

$\mathrm{P}\left(\mathrm{TCIF} \_\right.$Persepsi Individu $)=\mathrm{f}(\mathrm{SPKW}, \mathrm{PAN}-\mathrm{TL})$ 


\section{DAFTAR PUSTAKA}

Adrianto, L., 2004. Analisis Penentuan Daerah Perikanan (Fisheries Dependent Region). Working Paper. Pusat Kajian Sumberdaya Pesisir dan Lautan IPB, Bogor.

Armstrong, J. E.; Anderson, R. A.; J. S. Fralish; P. K. Benjamin, 1993. The Ecology and Biology of Panax quinquefolium L. (Araliacea) in Illinois. American Midland Naturalist: 357372.

Bengen, D. G., 2002. Menuju Pengelolaan Wilayah Pesisir Terpadu Berbasis DAS. Seminar HUT LIPI, Jakarta.

Badan Pusat Statistik Republik Indonesia Tahun 2005, Jakarta

Badan Pusat Statistik Republik Indonesia Tahun 2006, Jakarta

Balint, Z., 2005. A Review of The Neotropical Hairstreak Genus Annamaria with Notes on Further Genera.

Briguglio, L. 1995. Small Island Developing State and Their Economic Vulnerabilities. World Development, 23 (9), 1615-1632.

Departemen Permukiman dan Prasarana Wilayah Direktorat Jenderal Penataan Ruang, 2002. Strategi dan Konsepsi Pengembangan Kawasan Perbatasan Negara.

Dinas Perikanan dan Kelautan Provinsi Maluku, 2005. Profil Pulau Perbatasan (Pulau Penambulai) Kabupaten Kepulauan Aru. Laporan, Ambon.

Direktorat Jenderal Pengawasan dan Pengendalian Sumberdaya Kelautan dan Perikanan (Ditjen P2SDKP), 2008. Refleksi 2007 dan Outlook 2008 Pengawasan dan Pengendalian Sumberdaya Kelautan dan Perikanan, Jakarta. 65 hal.

Echols, J. M. and Hasan S., 2002. Kamus Indonesia-Inggris. Penerbit Gramedia Pustaka Utama, Jakarta. 618 hal.

Food and Agriculture Organization (FAO), 1999. FAO Technical Guidelines for
Responsible Fisheries. Fishing Operation, Rome. 26 p.

Food and Agriculture Organization (FAO), 2001. International Plan of Action to Prevent, Deter and Eliminate Illegal, Unreported, and Unregulated Fishing, Rome. 24 p.

Food and Agriculture Organization (FAO), 2002. Working with Local Institution to Support Sustainable Livelihoods, Rome. 23 p.

Keputusan Menteri Kelautan dan Perikanan Republik Indonesia Nomor 41 tahun 2000 tentang Pedoman Umum Pengelolaan Pulau-Pulau Kecil.

Keputusan Presiden Republik Indonesia Nomor 63 tahun 1999 tentang Pencabutan Keputusan Presiden Nomor 44 tahun 1994 tentang Badan Pengendali Pelaksanaan Pembangunan Wilayah Perbatasan di Kalimantan.

Keynes, J. M., 1936. The General Theory of Employment, Interest and Money. http://homepage.newschool.edu/het //texts/keynes/gtcont.htm.

Kusumastanto, Tridoyo. 2004. Ocean Policy dalam Membangun Negeri Bahari di Era Otonomi Daerah. Gramedia Pustaka Utama. Jakarta. 2004.

Lee, S. E., 1991. Teori Migrasi, Terjemahan oleh Hans Daeng. Pusat Penelitian Kependudukan Universitas Gadjah Mada, Yogyakarta.

Mataram, H., 1990. Hukum Humaniter dengan Doktrin Hankamrata. Penerbit UNS Press., Surakarta.

Mukhtar, 2008. Tata Laksana Perikanan Yang Bertanggungjawab. Makalah. Satuan Kerja Pengawasan Sumberdaya Kelautan dan Perikanan, Kendari.

Munir, A. M., 2004. Teologi Pinggiran dalam Kehidupan Wong Cilik. Penerbit Grafinso Khazanah Ilmu, Jakarta. 371 hal.

Monk, K. A. et al., 1997. The Ecology of Nusa Tenggara and Maluku. Periplus Edition (HK), Singapore, 966 p. 
Nikijuluw, V. P. H., 2005. Politik Ekonomi Perikanan. Bagaiamana dan Kemana Bisnis Perikanan. Penerbit PT. FERACO, Jakarta. 316 hal.

Nikijuluw, V. P. H., 2008. Blue Water Crime. Dimensi Sosial Ekonomi Perikanan Ilegal. Penerbit PT. Pustaka Cidesindo, Jakarta. 196 hal.

Pemerintah Republik Indonesia. 2008. Undang-Undang Republik Indonesia Nomor 43 Tahun 2008 tentang Wilayah Negara.

Peraturan Presiden Republik Indonesia Nomor 78 Tahun 2005 tentang Pengelolaan Pulau-Pulau Kecil Terluar.

Raai, A. R., 2001. Konflik Laut Cina Selatan dan Ketahanan Regional Asia Pasifik Sudut Pandang Indonesia. Penerbit APSINDO, Jakarta.
Retraubun, A. S. W., 2007. Pulau Kecil di Tengah Pemanasan Global. Harian Kompas Tanggal 2 Juni 2007, Jakarta.

Rijanta, R., 2005. Insularity and Development in Indonesia: Toward a Conceptual Model on The Backwardness of Small Islands. Magazine, Jakarta.

Saleh, C., 2000. Strategi Pengembangan Perekonomian Rakyat dan Koperasi di Daerah. Jurnal Ilmiah Administrasi Publik. Volume 1 Nomor 1. Universitas Brawijaya, Malang.

Seers, D., 1972. The Prevalence of Pseudoplanning, London. 